\title{
"These Trees Have Stories to Tell": Linking Dënesọłıné Oral History of Caribou Use with Trample Scar Frequency on Black Spruce Roots at Pedacho Kué
}

\author{
Kelsey L. Dokis-Jansen, ${ }^{1}$ Brenda L. Parlee, ${ }^{2}$ Łutsël K'e Dëne First Nation, ${ }^{3}$ David S. Hik, ${ }^{4}$ Benoit Gendreau- \\ Berthiaume, ${ }^{5}$ Ellen Macdonald ${ }^{6}$ and Christina Stinn ${ }^{7}$
}

(Received 19 October 2020; accepted in revised form 14 April 2021)

\begin{abstract}
For thousands of years Pedacho Kué (Artillery Lake, Northwest Territories) has been a key water crossing site for barren-ground caribou (Rangifer tarandus groenlandicus). Human disturbance of barren-ground caribou habitat in northern Canada has emerged as an important focus of study in the last decade; particularly in the Bathurst range of the Northwest Territories where caribou populations have declined by more than $95 \%$ since the 1980 s. Guided by local Indigenous leaders and Elders, a collaborative research project was developed with the Dënesọ́łıné people of Łutsël K’e Dëne First Nation (2012 -14). This paper describes linkages between knowledge derived from Dënesọ́łıné oral history and quantitative dendroecological analysis of trample scars on black spruce (Picea mariana) root samples collected at Pedacho Kué to provide a better understanding of caribou use at this location. Findings from oral histories and dendroecology analysis were consistent with one another and with previous dendroecology study in the region, although some discrepancies were detected in data from 1995-2006 that require further study to elucidate. Key findings include relatively low caribou use at Pedacho Kué during the 1930s and late 1960s, with use increasing into the 1970s and peaking in the late 1980s, as well as Elder and hunter reports of no caribou in some years between 2005 and 2012. This work addresses a gap in scientific data about barren-ground caribou movements at Pedacho Kué prior to satellite collar use in 1996 and corroborates previously documented oral histories about the enduring value of Pedacho Kué as critical habitat to barren-ground caribou. Given the drastic decline of the Bathurst caribou over the last two decades, more research is needed to understand movements and their relationship to population dynamics. In this context, the research approach described in this paper could be used as an example of how to meaningfully bring together place-based Indigenous knowledge and science in addressing an urgent issue of Arctic sustainability.
\end{abstract}

Key words: caribou; Rangifer; sub-Arctic; Indigenous knowledge; Dënesọ́łné; Łutsël K’e; dendroecology; Northwest Territories; place-based research; collaborative community-based research

RÉSUMÉ. Depuis des milliers d'années, Pedacho Kué (lac Artillery, Territoires du Nord-Ouest) sert d'important point de franchissement de cours d'eau pour le caribou de la toundra (Rangifer tarandus groenlandicus). La perturbation anthropique de l'habitat du caribou de la toundra dans le Nord canadien a fait l'objet d'études importantes ces dix dernières années, plus particulièrement dans l'aire de répartition de Bathurst, dans les Territoires du Nord-Ouest, où les populations de caribous ont chuté de plus de $95 \%$ depuis les années 1980. Un projet de recherche collaborative guidé par des chefs et des aînés autochtones locaux a été conçu en consultation avec le peuple Dënesớłıné de la Première Nation Łutsël K’e Dëne (2012-2014). Cet article décrit les liens entre les connaissances dérivées de l'histoire orale des Dënesọ́łınés et l'analyse dendroécologique quantitative des cicatrices de piétinement se trouvant sur les échantillons de racines d'épinettes noires (Picea mariana) prélevés à Pedacho Kué afin de mieux comprendre l'utilisation de ce lieu par les caribous. Les constatations découlant de l'histoire orale et de l'analyse dendroécologique concordaient ensemble ainsi qu'avec une étude dendroécologique antérieure de la région, bien que certains écarts aient été décelés dans les données de 1995 à 2006, écarts qui se doivent d'être étudiés afin d'être élucidés. Parmi

\footnotetext{
${ }^{1}$ Corresponding author: Department of Resource Economics and Environmental Sociology, University of Alberta, Edmonton, Alberta T6G 2H1, Canada; current address: Faculty of Native Studies, University of Alberta, Edmonton, Alberta T6G 2H8, Canada; kljansen@ualberta.ca

${ }^{2}$ Department of Resource Economics and Environmental Sociology, University of Alberta, Edmonton, Alberta T6G 2H1, Canada

${ }^{3}$ Wildlife, Lands and Environment Office, Box 28, Łutsël K'e, Northwest Territories X0E 1A0, Canada

${ }^{4}$ Department of Biological Sciences, University of Alberta, Edmonton, Alberta T6G 2E9, Canada; current address: Department of Biological Sciences, Simon Fraser University, Burnaby, British Columbia V5A 1S6, Canada

${ }^{5}$ Department of Renewable Resources, University of Alberta, Edmonton, Alberta, T6G 2H1, Canada; current address: ISFORT, UQO, 58, rue Principale, Ripon, Québec J0V 1V0, Canada

${ }^{6}$ Department of Renewable Resources, University of Alberta, Edmonton, Alberta T6G 2H1, Canada

${ }^{7}$ Department of Renewable Resources, University of Alberta, Edmonton, Alberta T6G 2H1, Canada; current address: Department of Conservation Biology, University of Göttingen, Göttingen, Germany

(C) The Arctic Institute of North America
} 
les principales constatations, notons l'utilisation relativement faible de Pedacho Kué par les caribous pendant les années 1930 et la fin des années 1960, une utilisation accrue dans les années 1970 ayant atteint un sommet vers la fin des années 1980, ainsi que le signalement de l'absence de caribous par les aînés et les chasseurs au cours de certaines années entre 2005 et 2012 . Notre recherche comble un manque de données scientifiques relativement aux déplacements du caribou de la toundra à ?edacho Kué avant que les colliers émetteurs à transmission par satellite ne commencent à être employés en 1996. Elle corrobore l'histoire orale documentée précédemment au sujet de la valeur durable de ?edacho Kué en tant qu'habitat critique du caribou de la toundra. En raison de la chute importante de la population du caribou de Bathurst ces deux dernières décennies, de plus amples recherches s'imposent afin de comprendre les déplacements et leur lien avec la dynamique de la population. Dans ce contexte, la démarche de recherche décrite dans cet article pourrait servir d'exemple montrant comment concilier les connaissances autochtones d'un endroit avec la science pour faire face à un enjeu urgent de durabilité de l'Arctique.

Mots clés : caribou; Rangifer; subarctique; connaissances autochtones; Dënesọ́łıné; Łutsël K’e; dendroécologie; Territoires du Nord-Ouest; recherche axée sur les lieux; recherche communautaire collaborative

Traduit pour la revue Arctic par Nicole Giguère.

\section{INTRODUCTION}

The stresses on global biodiversity are growing, with species declines evident in many parts of the world, including the Arctic (IPBES, 2019; Taylor et al., 2020). Populations of barren-ground caribou (Rangifer tarandus groenlandicus) are among those species that have declined significantly across the circumpolar North (Vors and Boyce, 2009; COSEWIC, 2016). Among the caribou herds in steepest decline is the Bathurst caribou herd, which has declined by $98 \%$ (from over 470,000 animals over two years old to approximately 8200) since the mid 1990s (COSEWIC, 2016; Adamczewski et al., 2019). Scientists in the region attribute this decline to natural variability, climate change, predation, hunting, and the influence of resource development (COSEWIC, 2016; Adamczewski et al., 2019). However, many Indigenous peoples in the Bathurst range argue that large-scale resource development is the major driver (Jacobsen et al., 2016; MVEIRB, 2016; Parlee et al., 2018). As stated by the late Chief of Łutsël K'e Dëne First Nation ( $\mathrm{K}$ KFN), mining is "driving the caribou away" (Antoine Michel in CBC News, 2011). It is in this context that a collaborative study of movement patterns of the Bathurst caribou was initiated based on Indigenous knowledge and methods of dendroecology.

Dënesọłlné harvesters and other Indigenous peoples in Canada have long embraced the dynamic nature of caribou and other valued species (Berkes et al., 2000). Their success at coping with variability in both distribution and population is evident in their strong culture, economies, and food systems, which are highly reliant on the seasonal migration of caribou into their traditional territory in fall and winter months (Smith, 1978; Parlee et al., 2005a). But given that caribou movements are highly variable, determining the degree to which mining is "driving the caribou away" is challenging when approached through linear models of cause and effect. The natural variability in seasonal movement patterns makes the survey of caribou range use by satellite collar data somewhat unpredictable. With relatively few collared animals for some years, it can be difficult for wildlife managers to gain a full picture of range use from year to year (Gunn et al., 2011). Although technology is improving, and innovations (e.g., drones) have made tracking caribou less costly, historical records of caribou movement patterns are limited. Aerial surveys and satellite collaring have provided information about some aspects of herd movement in the region from 1996-2010 (Boulanger and Gunn, 2007; Boulanger et al., 2011; Gunn et al., 2011). Prior to this period, data on caribou distribution and movements are limited, particularly for their fall and winter ranges. This absence of information has made it difficult to articulate the impacts of increased mining activity on caribou movement patterns and population, particularly following the discovery of diamonds and the sharp increase in mining exploration and development in the early 1990 s.

While methods of aerial survey and satellite collaring for studying caribou range use have been adopted relatively recently, other information and methodologies associated with traditional land-use studies, such as oral histories from Elders and harvesters, offer the potential for a much longer perspective and an added sociocultural context about caribou availability in places of combined ecological and sociocultural significance (Huntington, 1998; Gordon, 2005; Anadón et al., 2009). Numerous studies point to the systematic observation and recollections that are particularly well developed and reliable among Elders and harvesters who are recognized as experts by their communities for extreme events or large game, such as barren-ground caribou, which feature prominently in the cultures, economies, and diets of the community (Berkes, 1983; Pedersen and Coffing, 1984; Usher and Wenzel, 1987; Davis and Wagner, 2003; Kutz et al., 2005; Lyver and Łutsël K'e Dëne First Nation, 2005; Peloquin and Berkes, 2009; Rist et al., 2010; Polfus et al., 2016).

Over hundreds if not thousands of years, northern Indigenous peoples, including the Dënesółıné, have developed ways of interpreting and coping with the variability in caribou movements across a vast landscape (Smith, 1978; Parlee et al., 2005a). "[By] monitoring of caribou at key water crossings during the fall migration, hunters made observations about caribou health, 
population, and movement patterns" (Parlee et al., 2005a), and these historic practices have been adapted in a contemporary context. Although hunters no longer live and travel in these areas year-round, there is still active use and monitoring of caribou use at these key crossings during the fall and winter hunting season. These water-crossing sites, Peda in Dënesớłıné language, are among a few areas of the range (save for calving areas and summer ranges) to which caribou are shown to exhibit common fidelity or consistent use from year to year. The value of these water crossings as places of combined socio-ecological significance has resulted in a growing effort to document water crossings as cultural landscapes, archaeological sites, as well as indicators of caribou movement both in North America and in other parts of the circumpolar North (Baskin, 2003; Stewart et al., 2004; Parlee et al., 2005b).

Previous research has shown that Dënesớłıné Elders understand caribou movements in the region according to these critical water crossings, which funnel caribou through the taiga landscape in relatively predictable ways (Parlee et al., 2005a). These crossing sites act as natural corrals and concentrate caribou use at the narrows of large water bodies. Consequently, the Dënesọ́lıné, like other Indigenous peoples living within the caribou range, do not consider movement patterns to be infinitely uncertain (Parlee et al., 2005a). The importance of this funneling effect can be understood at a finer scale through the study of caribou trails at water-crossing sites. A previous study documented the historic observations and comparison of the distribution of differently aged trails on the landscape that allowed for Dënesớł1né to make decisions about where and when to harvest caribou (Parlee et al., 2005a). Contemporary Dënesớł1né hunting strategies draw from these historic practices and continue to focus on key water crossings as sites where caribou are most likely to be found.

Another approach to mapping historical caribou use and population involves the analysis of historical records of trample scars formed on tree roots by developing chronologies of caribou range use at key sites, a method that has been employed in the Northwest Territories and in northern Québec (Morneau and Payette, 1998, 2000; Boudreau et al., 2003; Payette et al., 2004; Zalatan et al., 2006). The method, originally developed by Morneau and Payette (1998), proposed the use of dendrochronology analysis of trample scars formed primarily on the roots of black spruce (Picea mariana) that grow across caribou trails, as an indicator of caribou use over historical time periods of at least 100 years. Additional application of this method was further explored in subsequent studies in northern Québec, establishing the method as an effective approach in detailing historical records of fine-scale caribou use during snow-free periods (Morneau and Payette, 2000; Boudreau et al., 2003; Payette et al., 2004). The extent to which these past studies have examined links with local Indigenous knowledge has been somewhat limited. In 2006, Zalatan et al. employed the dendroecology methods established in Québec to determine caribou use and abundance in the Bathurst and Beverly caribou range and incorporated oral history information in their site selection and data analysis. They determined study site locations and verified the outcomes of their data through reference to a published traditional knowledge study that was conducted in the region with Tị́chą Elders and knowledge holders (Legat et al., 2001).

Gaps in the availability of documented oral histories, challenges around how best to link such traditional knowledge and scientific data, as well as time and resource constraints all contribute to the limited extent to which Indigenous knowledge and dendroecology data have been studied together. Differences in the temporal scale, spatial scale, methodology, and format in which knowledge is communicated are challenges that have been well articulated in the bridging of Indigenous and scientific approaches to environmental study (Agrawal, 1995; Duerden and Kuhn, 1998; Berkes et al., 2000; Ellis, 2005; Gagnon and Berteaux, 2009). Mirroring those welldefined challenges, it has been the case over the past few decades that traditional knowledge and caribou science have been pitted against one another in environmental assessment hearings and other kinds of co-management forums, including harvest management planning processes (Nadasdy, 2003; Ellis, 2005). Increasingly, however, the potential for common ground and collaboration between local Indigenous knowledge and science in wildlife management is being explored (Danielsen et al., 2014; Service et al., 2014; Cuyler et al., 2020).

In this paper, we address a fundamental question: How can dendroecology data and oral histories of Dënesọ́tıné Elders and hunters contribute to our understanding of historical movements of barren-ground caribou in the area of Pedacho Kué, located within the fall and winter range of the Bathurst and Beverly herds? This question is explored through interviews with hunters and Elders who have lived and hunted in the area, coupled with a dendroecological analysis of black spruce roots from caribou trails. The results presented provide site-specific data of caribou use in the region of Pedacho Kué from 1920 to 2012. In addition to the data presented about caribou activity and the oral history of Dënesọłıné peoples around Pedacho Kué, we also offer insights into the greater potential of linking science and Indigenous knowledge through collaborative, placebased research and co-production of knowledge.

\section{SETTING}

Łutsël K'e (formerly Snowdrift) is the most northerly Dënesớłıné community in Canada, located on the East Arm of Great Slave Lake approximately $200 \mathrm{~km}$ east of Yellowknife in the Northwest Territories (Fig. 1). The community is accessible by plane, boat, or snowmobile with a resident population of approximately 350 people. Łutsël K'e Dëne families began settling in the community in the 1950s, having previously lived and travelled across 


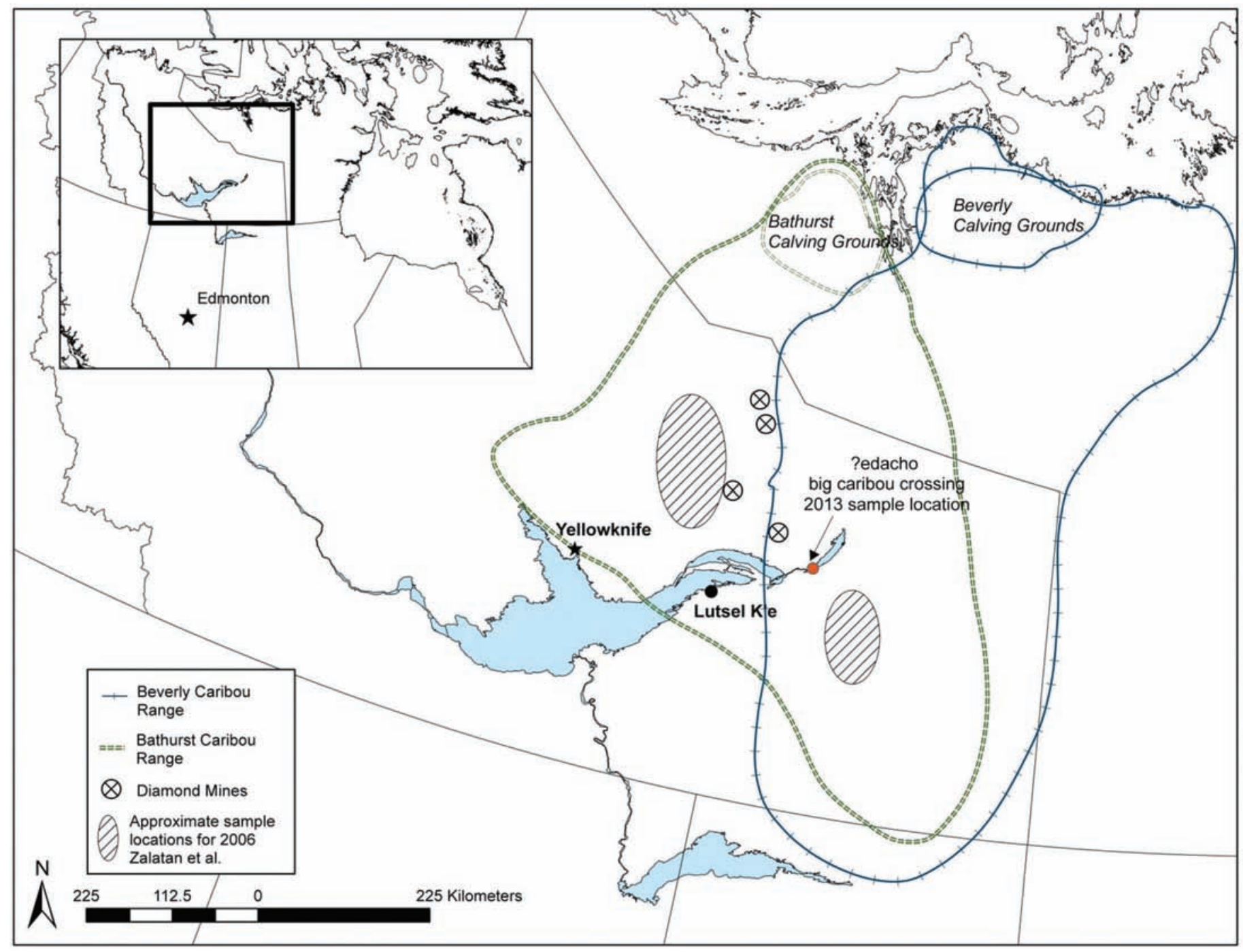

FIG. 1. Map indicating the range of the Bathurst and Beverly caribou herds, active diamond mines, our study site (Pedacho Kué), previous study sites (Zalatan et al., 2006), and the community of Łutsël K'e, NWT.

large expanses of the region, following migrating caribou herds and living in small villages or encampments on the East Arm and at Pedacho Kué.

Prior to European contact, the Dënesọłlné were recognized as the most widely travelled and populous of all northern Athabaskan language groups, with movement that mirrored migrating caribou herds (Smith, 1978; Kendrick et al., 2005). Despite the more settled lifestyle in recent years, many Dënesớłıné continue to hunt, trap, fish, and otherwise travel across large distances of their traditional territory, often travelling in areas spanning from Yellowknife east to the Thelon River and from Alymer Lake in the north to Nanacho Lake south of the current town site. The Pedacho Kué area and the Lockhart River that flows from Pedacho Kué into the East Arm of Great Slave Lake have been the core of Dënesớlıné territory for thousands of years. These places are deeply intertwined with individual and community identity and spirituality (Parlee et al., 2005b). Oral history accounts and archaeological evidence show that people have been hunting for caribou at Pedacho Kué since at least 3000 BC (Noble, 1971; Parlee et al., 2005a). Many Dënesọ́łıné stories, including "The Lady of the Falls" and "How the Bear Stole to Sun," are suggestive of Dënesốłıné knowledge of the area dating back to postglacial periods (Parlee et al., 2005b).

The herds defined as the Bathurst and Beverly caribou frequent a range of over $600,000 \mathrm{~km}^{2}$, which falls within the jurisdictional boundaries of the Northwest Territories, Nunavut, and Saskatchewan, an area which is also representative of overlapping territories of Dëne, Inuit, Nehiyawak (Cree), and Métis peoples. The distribution of caribou in the fall and winter range is considered highly variable and uncertain; ranges can vary considerably depending on a variety of habitat factors, including human disturbance (Nagy et al., 2005). Despite the multiplicity of caribou migration pathways, Dënesọ́l1né Elders understand caribou movements in their region according to critical habitat locations and their own particular relationships to those places. Among these locations are the water crossings, which act as natural 'corrals'-funneling caribou to the narrows 
of large water bodies at a small number of sites across their range (Willams and Gunn, 1982; Parlee et al., 2005b).

Dënesọ́tıné Elders and hunters in the Bathurst and Beverly range have highlighted the ecological and cultural significance of many such crossing sites, including those located at Pedacho Kué (Kendrick et al., 2005; Parlee et al., 2005b). The crossings at both the northern and southern points of Pedacho Kué have always been gathering places for the Dënesó́łıné in fall; the harvest of meat at that time was, and continues to be, critical to the health and food security of their families and communities (Kendrick et al., 2005; Parlee et al., 2005b). The place name itself, Pedacho Kué, or "lake of the big caribou crossing," demonstrates the ecological and cultural value of this place. Previous research and information collected during scoping interviews identified the importance of caribou trails, or etthën hutt'a and etthën kun, as an important sign of caribou activity in fall and winter, as well as etthën ekëlué (old caribou trails) as the basis for understanding historical changes in caribou movements (Parlee et al., 2005b). Although previous research has discussed the general significance of these areas, relatively little scholarly attention has been paid to the temporal variation of caribou activity at Pedacho Kué.

\section{METHODS}

\section{Community-Based Collaborative Approach}

The project was a collaboration between $Ł$ KDFN and the University of Alberta. Building on previous research collaborations between the second author and others (Kendrick et al., 2005; Lyver and Łutsël K'e Dëne First Nation, 2005; Parlee et al., 2005b), the ŁKDFN Wildlife Lands and Environment Committee (WLEC) sought to find ways to build their research capacity while at the same time increasing the understanding of the impacts of mining activity on caribou in their territory and specifically in the Pedacho Kué area shown in Figure 1. As a result, the long-term collaboration expanded to additional expertise in wildlife biology, Arctic ecology, and forestry (dendroecology). Elders and hunters from $Ł K D F N$ were integral in all phases of the research project. During the development of the research project, they made recommendations for potential participants, chose field site locations, and determined the best timing of research activities. In preparation for fieldwork, they set terms not only for ensuring the health and safety of study participants, but also for respecting caribou and caribou habitat. They also provided guidance and community requirements for the documentation, use, and reporting of study results as part of the community's Traditional Knowledge Archive, which houses over two decades of the community's research. In addition to caribou experts, 10 youth were involved in field research camps to participate in cross-cultural learning from Elders and graduate students from the University of Alberta. In addition to the cultural protocols for respecting the land, Tri-Council policies for research with Indigenous peoples were also followed. A framework of OCAP $^{\circledR}$ (ownership, control, access, and possession) guided the research such that the community owns and stores all data from the research project for their future use (Schnarch, 2004). Formal approvals for the project were obtained from the University of Alberta's Human Research Ethics Office (Study ID. Pro00026097), the Aurora Research Institute (Licence No. 15130), and through direct request for the research project from the WLEC and $\mathrm{E}$ KDFN Chief and Council, based on an ongoing research agreement between the second author and $Ł K D F N$.

\section{Semi-Directed Interviews}

Oral history research was carried out from 2012 to 2014. Specifically, semi-directed interviews with 10 Elders and four harvesters (10 men and 4 women) were held in the community as well as at Pedacho Kué. These included multiple individual interviews as well as focus groups, mapping activities, and on-the-land discussions. Those interviewed were recommended as experts by the WLEC because of their contemporary and intergenerational knowledge of the Pedacho Kué and skills as "good caribou hunters." Interviewees were also asked if there were other experts who should be included, and additional interviews were conducted until saturation was achieved.

Interviews were conducted in four phases and in both English and Dënesớłıné language, with a fluent language speaker acting as the community research assistant and translator in all of our interviews. Interview guides were followed, with the researchers and translator prompting follow-up to the responses based on the guiding questions. A list of example questions that guided each phase of the interviews with Elders and hunters is provided in Table 1. A separate workshop was held with Elders and hunters to document relative caribou use at Pedacho Kué. At this workshop participants were asked to recall extreme events and patterns in caribou density, including times when there were there many caribou, some caribou, few caribou, or no caribou at Pedacho Kué. Elders shared these insights based on their own observations and experience or memories shared by their parents, grandparents, or previous generations. The interviews were all audio- or video-recorded, and transcripts were made of each of the interview outcomes.

Once transcribed, themes were identified based on careful reading of the transcript material. The first phase of thematic coding attempted to determine the breadth and depth of discussion on caribou movements, signs of recent or historic use of trails, other important caribou crossings, and time-specific insights about caribou activity at Pedacho Kué. Analysis of the transcripts revealed insights about specific periods over the last century when there were "no caribou," "some caribou," or "lots of caribou" at Pedacho Kué. In addition to Elders sharing their own memories of these periods (dating back over 70 years), harvesters also 
TABLE 1. Example guiding questions during each interview phase.

\begin{tabular}{|c|c|c|}
\hline $\begin{array}{l}\text { Phase } \\
\text { No. }\end{array}$ & $\begin{array}{l}\text { Interview type, } \\
\text { time, and location }\end{array}$ & Example questions \\
\hline 1 & $\begin{array}{l}\text { Scoping interviews, } \\
\text { August 2012, Łutsël K'e }\end{array}$ & $\begin{array}{l}\text {-Where are the most important places to find caribou? } \\
\text { - Where do you usually go hunting for caribou? } \\
\text { there being low caribou at these places? } \\
\text { - If we were to hold a land camp to do more interviews and look for caribou trails, where would the best location be? } \\
\text {-Where is a good place to find a lot of caribou trails? }\end{array}$ \\
\hline 2 & $\begin{array}{l}\text { Land-based interviews, } \\
\text { September 2012, K’ásba Deze }\end{array}$ & $\begin{array}{l}\text { - Can you tell us about times in the past when there were lots of caribou here? } \\
\text { - How old were you or your children at that time? } \\
\text { - What can you tell from these trails? Have there been many caribou here recently? } \\
\text { - How wide would a really well-used caribou trail be? } \\
\text {-What is important for us to know if we are going to collect samples of tree roots from the caribou trails? }\end{array}$ \\
\hline 3 & $\begin{array}{l}\text { Verification interviews, } \\
\text { January 2013, Łutsël K'e }\end{array}$ & $\begin{array}{l}\text {-What do you recall about times when there were lots of caribou or no caribou? When was that? } \\
\text { - What do you think about the samples of tree roots we took? } \\
\text { - Why do caribou use different areas from year to year? }\end{array}$ \\
\hline 4 & $\begin{array}{l}\text { Sample site interviews, } \\
\text { September 2013, Pedacho Tłazi }\end{array}$ & $\begin{array}{l}\text {-Where do the caribou cross? Do these trails look recently used? } \\
\text { - How has this area changed in your lifetime? } \\
\text { - Were there years in your memory or your parents/grandparents' stories when there were no caribou here? }\end{array}$ \\
\hline 5 & $\begin{array}{l}\text { Group workshop, } \\
\text { Spring 2014, Łutsël K'e }\end{array}$ & $\begin{array}{l}\text { - The tree roots show that caribou might have been low during certain times, for example, around the } 1930 \mathrm{~s} \\
\text { and in some of our other interviews people talked about that time. Are there other stories about when caribou } \\
\text { were low in the } 1930 \mathrm{~s} \text {, especially around Pedacho Kué? } \\
\text { - During what periods were there the most caribou at Pedacho Kué? Many people we interviewed talked about } \\
\text { when caribou were very plentiful in the late } 1980 \text { s and early } 90 \text { s. Does everyone agree with that, are there } \\
\text { other stories? } \\
\text { - Is there agreement that in some years between the early } 2000 \text { s and now [2014], there have been times when } \\
\text { people could not find caribou at Pedacho Kué? }\end{array}$ \\
\hline
\end{tabular}

shared oral histories about caribou activity passed on from their parents and grandparents (i.e., a common narrative was that "there was never a time where there was no caribou"). Interviewees shared these insights within longer narratives about their own personal experience (e.g., family hunting trips). Where temporal insights had been shared according to life events (e.g., during the big flu epidemic, before or after she was married), these events were transposed to decadal periods.

The workshop held in April 2014 was attended by all interviewees and others interested in learning about the study outcomes. A synthesis of the interviews was shared by the researcher (lead author) and feedback requested about the accuracy of the temporal references and narratives. Deference in the workshop was given to the oldest Elders with the most experience and knowledge of the Pedacho Kué area. Following the workshop, a synthesis of the outcomes of the interviews was created, and excerpts from interviews were cross-referenced and mapped alongside the results of the dendroecological analysis (Fig. 2).

Outcomes of the study were then shared with the WLEC and through other formal and informal community engagements (e.g., workshops, community events, newsletters, meetings with Chief and Council) from 2016 to 2018. The manuscript for this publication was developed with input of staff of the WLEC and verified by the committee in 2016 and again in 2021. As part of the research agreement with the community, $Ł K D F N$ is included as the third author of this paper to acknowledge the collective intellectual property rights of the community (Giles and Castleden, 2008).

\section{Field Research Camps}

Two field camps were held as part of the research project. The first field camp was held at K'ásba Deze (Ptarmigan River), between K'ásba Kué (Ptarmigan Lake) $\left(63.6005^{\circ} \mathrm{N}\right.$ and $\left.107.4351^{\circ} \mathrm{W}\right)$ and Pedacho Kué $\left(63.1458^{\circ} \mathrm{N}, 107.8335^{\circ}\right.$ W). The second field camp was located at Pedacho Tłazi (Timber Bay) between Pedacho Kué and the headwaters of the Lockhart River $\left(62.9505^{\circ} \mathrm{N}\right.$ and $\left.108.2685^{\circ} \mathrm{W}\right)$. The first camp in 2012 involved 25 community members, including youth, Elders, and hunters. They accompanied the first and second author along with two University of Alberta students during the first week of September to a number of potential sampling sites to learn more about the areas that would most likely have a high number of caribou trails and trampled black spruce roots. These site visits also allowed for the development of Dënesớtıné guidelines for sample collection and input from Elders on considerations for respecting caribou and caribou habitat. During these day trips from camp, we shared information about the dendroecology methods that have been used in other regions and requested input from Elders about the suitability of this method to document changes to caribou use in the Pedacho Kué area. This step was integral in further establishing the parameters of the research relationship and in ensuring that Elders and community members agreed with the research plans and sample extraction. Upon reflection after one of our site visits, Madeline Drybones shared with us that "yes, I think this is a good idea ... those trees have stories to tell." The authors understand this type of engagement to be aligned with the community's expectations around 


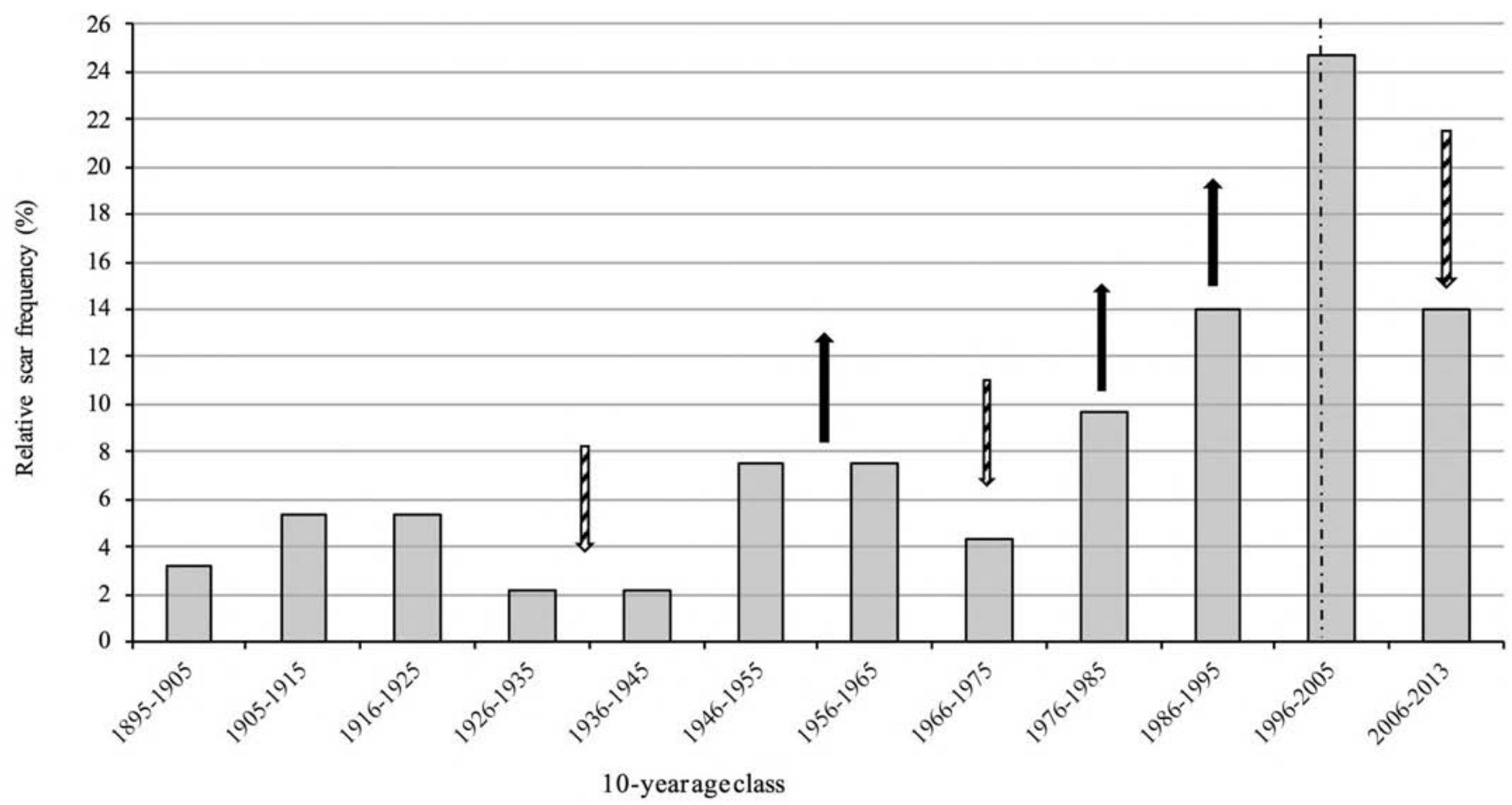

FIG. 2. Relative scar frequency (number of scars in each 10-year age class/total number scars for all samples) from 1895-2013 and Denésgliné oral histories of relative low (solid arrows) and high (dashed arrows) caribou use at Pedacho Kué and showing the beginning of diamond mine operation (dashed lined when the Ekati mine opened in 1998).

ethical conduct and adhering to the principles of OCAP ${ }^{\circledR}$ insofar as the community asserts its rights to have shared control over the collection of data within its own territory. In addition to the ethical reasons for this site scoping, there was opportunity for Elders to share site-specific oral history accounts of caribou use at Pedacho Kué during their lifetimes and to provide the researchers with additional context for understanding the important, interconnected relationships between these places, Dënesọ́ł1né, and caribou. Elders informed the research team that there were many well-used caribou trails at the south end of Pedacho Kué at Pedacho Tłazi (Timber Bay), as this area is known to be the most heavily used because of the narrow crossing, an obvious conclusion when we consider the place name itself, "big caribou crossing." It is interesting to note, however, that this 2012 camp was held at the north end of the lake as scouting trips prior to the camp identified that caribou were not near the big crossing, but farther north and east, closer to the K'ásba Deze camp.

\section{Dendroecological Sampling and Analysis}

During the second field research camp in mid-September 2013, four community researchers (two adults and two youth) travelled to Pedacho Tłazi to collect samples and worked with the lead author to identify areas with wide, well-used caribou trails, defined as Pechigháy boret'? where the roots and trample scars were visible. Five sampling areas were visited, with multiple caribou trails identified at each sampling site, including those considered the main caribou routes or 'roads' (Petthën kun) and associated side trails expected to be used heavily in years with high caribou use.

Two Dënesọ́łıné specific protocols were used for sampling. First, trail conditions were documented using Dënesớłıné terminology. Second, prior to any material being removed, tobacco was offered as directed by Elders. Central to Indigenous ethics, such protocol is commonly understood as an act of reciprocity when taking anything from the land; across Dëne homelands, this protocol is often referred to as "paying the land." Our sample collection thereafter closely followed that of Zalatan et al. (2006). We collected samples within $10 \mathrm{~m}$ from a central point at each sampling area. The central point was identified by a main caribou trail with visible roots showing visible indication of trample scars, including exposed xylem and resin accumulation. The sample areas were $100-500 \mathrm{~m}$ apart, starting at the most western ridge along Timber Bay. We travelled on foot, moving along caribou trails towards the peninsula at Pedacho. A total of 50 individual root sections ranging from 6-14 inches in length were collected, 10 root sections from each of the five sampling areas.

The root sections were cut using a handsaw, and lengths were selected to both capture root sections with visible indication of scarring and to minimize disturbance to the caribou trails as requested by the Elders. The roots were also marked to indicate which surface was facing up to allow for identification of trample scars, which would only be detected on the upward-facing side of each sample. The sample size of 10 samples per sampling area was based on the minimum samples per site collected by Zalatan et al. 
(2006). Two attempts were made to travel farther north by boat along the shore of the lake to gather samples from additional sampling areas, however inclement weather prevented the research team from reaching any additional sampling locations. Figure 3 shows examples of caribou trails and sample collection by community researchers and Figure 1 shows our sample locations relative to the sample locations of Zalatan et al. (2006).

Samples were stored in breathable (non-plastic) containers and transported to the Lutsël K'e townsite. Given limited facilities available in the community, the samples were transported to the University of Alberta for preparation and analysis. All samples were oven-dried at $60^{\circ} \mathrm{C}$ for 96 hours to remove all moisture. Each sample was cross-sectioned with four to seven cuts per sample using a table saw to ensure a perpendicular cut. Cuts were made by marking locations on the sample where visible damage to the cambium was evident, and additional markings were made approximately 1 inch apart. For example, a 6 -inch sample with outer damage at 1 inch from the end of the sample would then be cut into six equal segments approximately 1 inch per cut. This approach was used to ensure that our cross-sections would capture visible scars while also detecting scars that may be present but not show outer cambium damage. Each subsample cross-section was polished using progressively finer sandpaper $(220,320,400$, and $600 \mathrm{~mm}$ ) with an industrial-sized belt-sander according to preparation guidance from Stokes and Smiley (1968). All subsamples $(\mathrm{n}=269)$ were scanned at between 2400 and 6400 dots per square inch using a high-resolution scanner.

The software program CooRecorder 7.5 (Cybis Electronik \& Data AB, 2013a) was used to carefully crossdate and measure each sample. To ensure the most accurate chronology possible, the measurements to date the samples were made on the bottom side of the samples where growth rings were farther apart. The software program CDendro 7.5 (Cybis Electronik \& Data AB, 2013b) was used to convert the gross tree-ring widths for each year into normalized values by dividing the growth of each year by the average growth of the two preceding years (function "P2Yrs" of the CDendro software). Trampling scars were identified visually as shown in Figure 4 and dated using the chronology developed with CDendro. As described by Zalatan et al. (2006:626):

The seasonal dormant phase of the cambium extends over 2 calendar years (Morneau and Payette, 2000). It is not possible to determine the exact date that scars formed, as the year of scar formation could vary by +1 year. As a standard, the year of scar formation is taken as the most recent year.

(Morneau and Payette, 1998)

Following the established method of Morneau and Payette (1998), we only included scars that could be successfully cross dated in our final reporting of scar frequency. Once the date of scar formation was identified, the scar frequency distribution (using 10-yr age classes) was calculated to represent the relative level of caribou activity in the area; more specifically, we expected more scars across root samples in years with higher caribou activity. The limited number of samples and scars detected did not allow us to develop 5-year age classes (as in Zalatan et al., 2006). All materials (samples) are considered the property of $€ K D F N$. Digital scans of the roots are also located in the community. The root samples are currently being held at the University of Alberta until a storage facility is available in the community.

\section{Linking Dendroecology with Oral Histories}

A summary of relative caribou use by decade was developed from the oral history transcripts and compared with the tree-ring record and trample scar frequency. The two-day workshop held with $Ł$ KDFN Elders and hunters during the spring of 2014 allowed further assessment of the data outputs from both the interviews and the dendroecology assessment. Most participants of the workshop had been previously interviewed and had extensive knowledge of the Pedacho Kué area. The workshop's purpose was to verify the decadal descriptions of caribou activity from the individual interviews, to discuss or resolve any discrepancies between individual interview data, and to compare decadal characterizations of caribou activity at Pedacho Kué from the interviews and the dendroecology data. We subsequently compared directional trends in caribou abundance over decadal time blocks between the dendroecology and interview data. The examination with Elders and hunters of printed copies of the scanned cross sections showing approximate dates of scar formation also served as a catalyst for additional discussion around time-specified oral history accounts. The images of the roots and scars helped to further explore the usefulness of the dendroecology method itself from the perspective of the community, prompted more in-depth narratives describing variability in caribou use at Pedacho Kué, and provided additional sociocultural context of those observations.

\section{RESULTS}

\section{Description of Caribou Trails}

Elders and caribou hunters who participated in interviews and on-the-land research at Pedacho Kué offered many details about differences between trails and their usefulness in understanding caribou movements in the region. Lesser used and more heavily used trails were differentiated by many Elders. For context, Madeline Catholique described the width of a well-used trail to the tracks from a 4-wheel ATV (approximately 3.5 feet), while a lesser used trail is discussed more as "caribou tracks" or a single trail that has not been worn down over many years of use by large numbers of caribou (Fig. 3). 

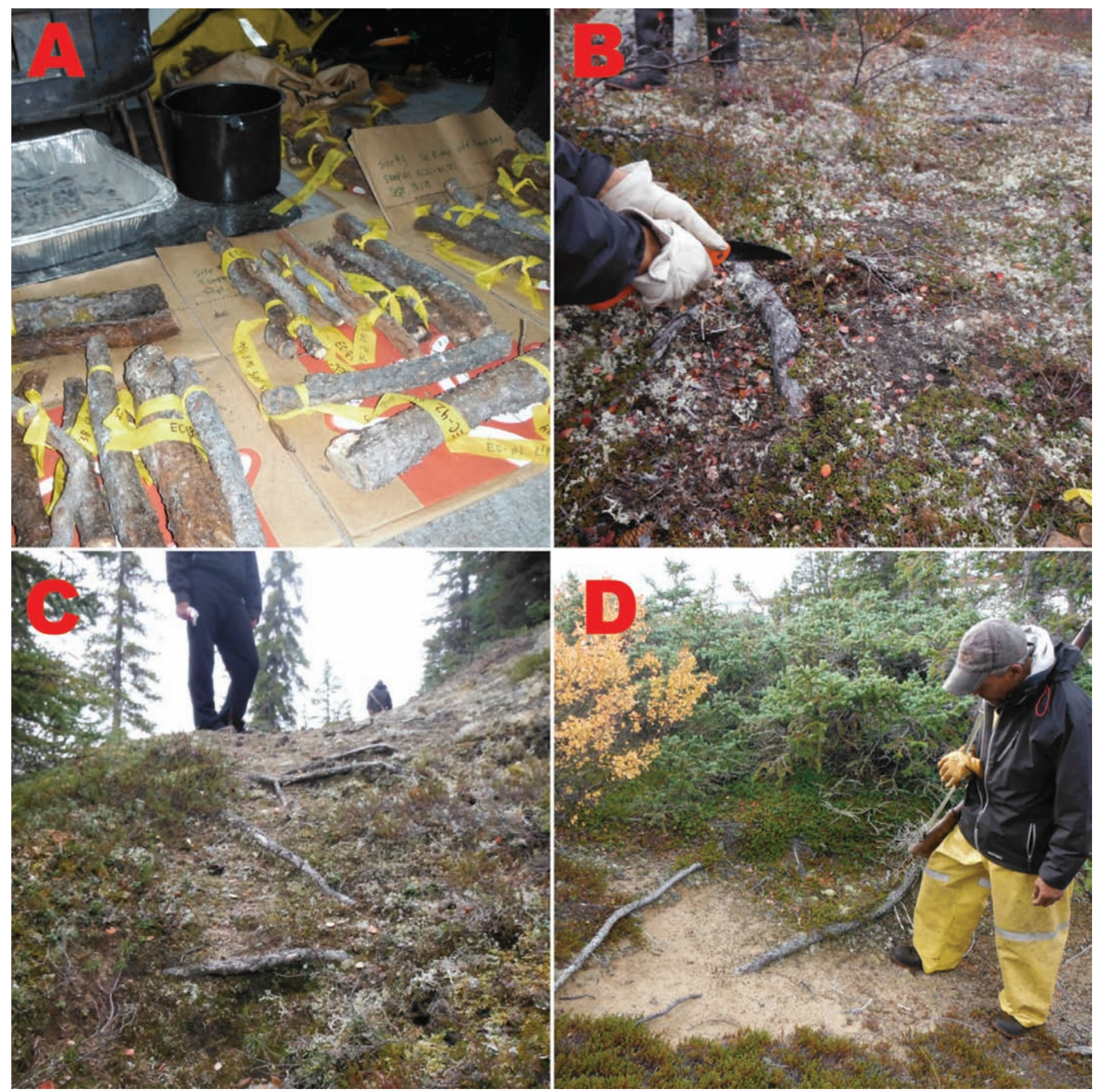

FIG. 3. Images of caribou trails and sample collection by community research assistants. (A) Black spruce root samples drying in the field prior to transport; (B) Sample extraction using a hand saw; (C) Older caribou trail with exposed roots evidenced by vegetation growth including some lichen, which have a long growth period; (D) Pete Enzoe assesses caribou trail conditions while searching for suitable sample locations.

Elders also differentiated between trails with exposed soil with worn-down roots and ones that had been grown over with vegetation. "I know that a caribou trail used a lot will wear the roots down; they even had trails in the sand ridges, now nothing" (Madeline Drybones, Ptarmigan River, 2012). Many Elders also pointed out the clear difference between the main caribou trail and secondary trails. “There's all kinds of caribou trails but there's one main road that they all use. The caribou know it" (Pierre Marlowe, Łutsël K’e, 2012).

There was also differentiation between trails used in later summer and fall and those used in winter.

Caribou trails in wintertime are like trails on the land [in summertime] in the muskeg, some caribou trails you can't see, vegetation has grown on some of the trails, 


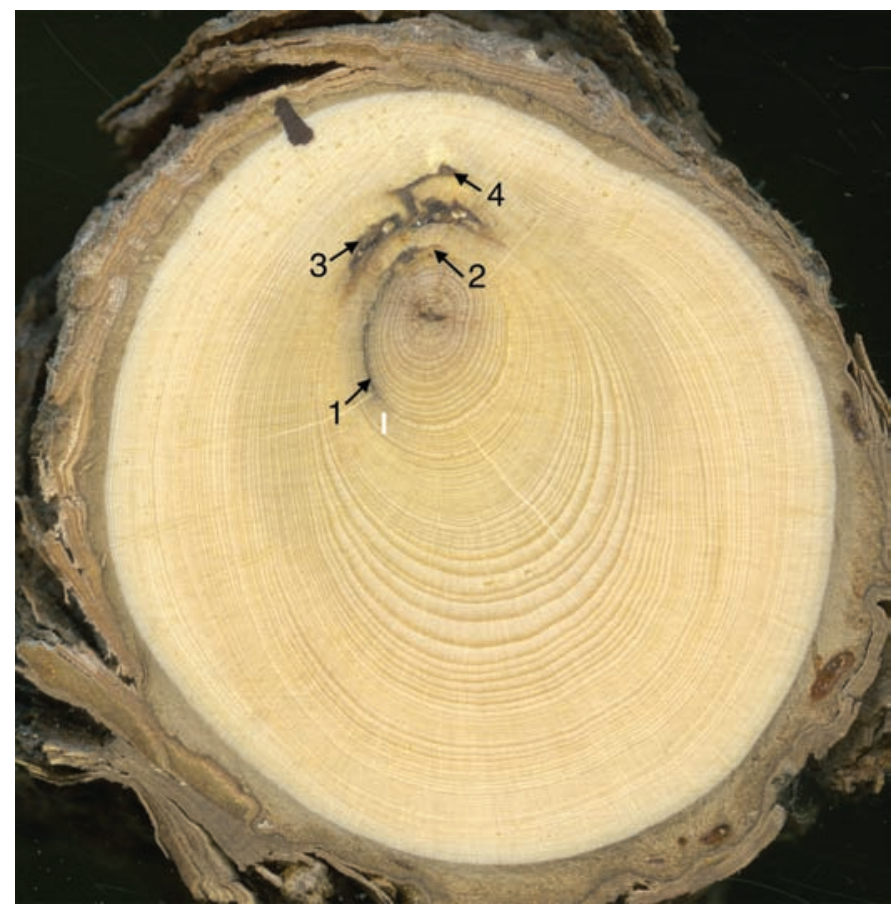

FIG. 4. Example of cross-section with caribou trample scars. (1) 1912, (2) 1926, (3) 1945, and (4) 1970.

that means it's not being used much. All year round there is caribou around Pedacho Kué. It used to be like that. And now the mines are sitting on the caribou trails.

(Madeline Drybones, K’ásba Deze, 2012)

The typology expressed through Dënesọ́t1né trail names was used to interpret changes in caribou movements in the region, including changes associated with increasing mining activity.

Around that place we were at [Ptarmigan River] for caribou, like I said, there always been caribou there before the mine has taken place, there is less caribou [now]. That's probably why the caribou trail you seen was not used as much. Maybe a few will go by, because they are all spread out, they get split up.

(Joseph Catholique, Lutsël K’e, 2013)

Madeline talked specifically about her observations at a mine site and the changes in caribou use over a two-year period:

Around Diavik area we walked around on the land ... Two years later I went back, there were no caribou, they made their trail elsewhere, they are moving further north.

(Madeline Drybones, K’ásba Deze, 2012)

\section{Oral Histories about Caribou Use at Pedacho Kué}

Workshops and interviews with Elders were carried out prior to and during tree-root sampling and following the dendroecology analysis. Of the 14 individuals interviewed, all were able to identify historic patterns in caribou activity at Pedacho Kué. Three categories detailing decadal changes in caribou movements were developed based on interview data: years when there were many caribou, years of few caribou, or years with no caribou. The majority of Elders and hunters (12 of 14) offered that there had always been caribou at Pedacho Kué in their lifetimes. Those who did not offer such description noted that they had not lived or hunted around the Pedacho Kué area during certain periods of time so would not comment with certainty. More detailed discussions resulted in insights that there had been relatively few caribou during the mid 1930s, the early 1970 s, and since the early 2000 s, with the last 10 years $(2002-12)$ marking an unprecedented decline not experienced before.

The Pedacho Kué area was emphasized by all interviewees as a place where people could depend on always finding caribou until recent years. The late 1970s to 1990s were consistently discussed as a period when people saw many caribou - or "so many caribou that everyone was coming to our community" (Joseph Catholique, Łutsël K'e, 2013). According to older interviewees, there were few caribou during the 1930s up until the 1960s. Some interviewees made associations between the decline in the 1930s to the increase in "white trappers" in the area. The decision of the government to poison wolves in the 1930s to limit predation of the herd stands out in the memory of Elders. For example:

Do you remember years ago, you probably don't even know ... before me, the government put out poison for wolves because caribou was running so low, so they [wolves] killed all the caribou? It might happen again, lots of wolves now. Yeah, that was to bring the caribou back up. Back then my dad used to tell me those stories they used to run into wolves in 30 or 40 in a pack, you can't go close to them. That was in 1930s. I wasn't even born then, but just through those stories.

(Eddie Drybones, Łutsël K’e, 2013)

In addition to these details about caribou in the Pedacho Kué area, interviewees also detailed other kinds of ecological changes in this area and the broader region. Among the regional patterns observed and experienced since the 1990s is the easterly shift in distribution of caribou away from areas currently under exploration and development. These observations were coupled with causal interpretations such as that offered here: "caribou have moved further east ... [could be] global warming or there's too much noise ... from the mining companies, the muskox were there for hundreds of years and all of sudden they find them in the bush" (Joseph Catholique, Łutsël K'e, 2012). Another pattern noted in the oral history related to the distribution of other wildlife, including moose and muskox. The shift in muskox distribution is of particular relevance, as there are no accounts in Dënesớtıné oral history of 
muskox venturing as far south as has been observed in recent years, as noted by Madeline Drybones (2012, K'ásba Deze):

\begin{abstract}
Muskox would mostly stay up at Thelon River; they never came down to Pedacho Kué before. When I was young, I use to shovel snow high as this tent, just to get wood, my daughter and me, by the time I was done, it's nighttime. When there was no caribou, people would go for muskox on the Thelon River.
\end{abstract}

Interviews also identified another pattern of change attributed to climate or global warming, specific to the treeline and caribou movement patterns along the treeline. Pete Enzoe describes the northeasterly shift in the use of key crossing sites from the East Arm of Great Slave Lake (Pike's Portage) to K'ásba Deze at the north end of Pedacho Kué:

Before they used to pass here, eh? [?edacho Kué]. Yeah, now they keep moving [farther north and east]. Yeah, a long time ago it used to be here [Kache], and it used to be here [farther east of Pike's Portage], here [faurther east], here [?edacho Kué], and now it's here [Ptarmigan River]. And then the trees growing, too, way back when I was growing up, the trees were far apart, and now it's growing thicker. Yeah, the climate is changing.

(Pete Enzoe, K’ásba Deze, 2012)

Many hunters have also observed that caribou travel in smaller groups during fall and winter when compared to earlier years, a pattern attributed to mining disturbance in the range.

Yeah ... for the caribou it's — caribou are further east all the time, sometimes they are scattered all over, you don't expect them, but all of sudden they are there. Smaller groups like 10-15 like that, sometimes 2 or 3, it's never been like that before, all the mining companies, they disturb them. Disturb the muskox and the caribou.

$$
\text { (Joseph Catholique, Łutsël K’e, 2012) }
$$

Some interviewees also spoke about the caribou being sick and unhealthy in recent years.

It only started after they built that mines up north there, Ekati and Diavik. That's the only time it started, you know, going all over. Like they were sick for a while, for a good maybe 6-7 years, I notice that because I'm a hunter. But now you don't see that, the bad things that was on them before. Even under the skin, yeah. But now I don't see too much of that, they probably know not to go around the mines anymore or something. They are smart animals, I know that, only one thing happen[s] to them and then they never go back there. You would
TABLE 2. Ten-year age class, number of trample scars, and frequency by age class (number of scars divided by total number of scars).

\begin{tabular}{ccc}
\hline \hline 10-year age class & No. of scars & Frequency by age class \\
\hline $1895-1905$ & 3 & 3.2 \\
$1906-1915$ & 5 & 5.4 \\
$1916-1925$ & 5 & 5.4 \\
$1926-1935$ & 2 & 2.2 \\
$1936-1945$ & 2 & 2.2 \\
$1946-1955$ & 7 & 7.5 \\
$1956-1965$ & 7 & 7.5 \\
$1966-1975$ & 4 & 4.3 \\
$1976-1985$ & 9 & 9.7 \\
$1986-1995$ & 13 & 14.0 \\
$1996-2005$ & 23 & 24.7 \\
$2006-2013$ & 13 & 14.0 \\
\hline \hline
\end{tabular}

think that the next one would go there, no, I think they've got one mind.

(Eddie Drybones, Łutsël K’e, 2013)

\section{Dendrochronology Analysis}

A total of 93 trampling scars were identified from the 50 root sections (269 subsamples). Roots were dated to be as old as 199 years, and the oldest trample scar (sample 15-C) was dated to 1895-1905 (Table 2). Despite the low sample size of roots, some clear temporal trends were apparent. Scar frequency by 10 -year age class was variable but generally increased over time. A known issue with quantification of trampling scars is the inevitable underestimation for older time periods because of scar loss that results from the death of roots or fewer roots of older ages (Zalatan et al., 2006). This issue has been addressed in previous applications of this method through the use of log-linear regression. However, due to the limited number of scars and samples we had available, we did not undertake a log-linear regression. Still, there were clear trends of relatively higher and lower numbers of scars at time periods that aligned with previous dendroecology studies and with the oral histories offered by Elders and hunters from Łutsël K'e. The greatest frequency of scars $(24.7 \%)$ was detected during the period of 1996-2005, and the lowest frequencies (2.2\%) were during the periods of $1926-35$ and 1936-45 (Table 2, Fig. 2). The summaries of Elder and hunter reports of relatively low and high caribou activity are mapped alongside the scar frequency distribution, showing low caribou activity in the 1930s and 1970s and increasing activity after the 1970s, peaking in the mid-1990s and then declining since that time as shown in Figure 2. Not shown on the graph is the report of no caribou found at Pedacho Kué in most years between the early 2000s and 2013 when this study was conducted. A comparison with results from Zalatan et al. (2006) indicates a similar pattern of relative increase and decrease in caribou activity over the same period of time (1900-2000), consistent with both their trample scar data and cited cross-validation with published Indigenous knowledge study with Tị́chą Elders: 
The information from the Dogrib Elders and the scars both showed low numbers of caribou during the 1920s, followed by a high peak in caribou numbers during the mid-1940s, then a low period from 1950 to 1970 . The aerial photography data showed an increasing trend in caribou abundance after the 1970 s, with a peak in the mid-1980s, followed by a significant drop in caribou abundance in 2000 .

\section{(Zalatan et al., 2006:626)}

There are some discrepancies in the data offered by the tree roots, oral histories, and previous research during the time period of 1995-2006. Elders and hunters clearly articulate that since the early 2000s, caribou use at Pedacho Kué has dropped significantly, a trend mirrored in the dendroecology results from previous work within the Bathurst and Beverly fall and winter range (Zalatan et al., 2006). Our trample scar data, however, show an increase during this time period. Although our data are not sufficient to make definitive claims, we offer two possible explanations for these discrepancies. The increase in scar frequency from 1995 to 2006 may be reflective of the peak in population of the Bathurst herd in the early 1990s and, because our tree root data set is limited, the decrease from 2000 to 2006 is not detected. The second potential explanation is that this increase indicates a contraction of the range, concentrating caribou use at this site during the years leading up to the 2000-06 despite a downward population trend across the range as documented in population survey data (COSEWIC, 2016).

\section{DISCUSSION AND CONCLUSIONS}

Over the last two decades, tensions around caribou management have been amplified in the Bathurst caribou range as a result of declining caribou numbers and increased disturbance of sensitive caribou habitat (COSEWIC, 2016; GNWT, 2019). Some of these tensions are owing to the uncertainties about caribou movements in the Bathurst range prior to the mid-1990s. Some scientists argue that there is too little evidence that increased mining activity over the last 20 years in the region is the cause of changes in caribou movements and population declines (Nishi et al., 2018). However, much documented Indigenous knowledge does attribute the decline in the health and population of the Bathurst herd to mining exploration and development between 1995 and 2005 (Legat et al., 2001; Thorpe et al., 2001; Parlee et al., 2005a; Kendrick and Manseau, 2008; ŁKDFN, 2016; GNWT, 2019; Wek'èezhìı Renewable Resources Board, 2019).

Building on previous dendroecology work related to caribou movements in northern Canada (Morneau and Payette, 1998, 2000; Boudreau et al., 2003; Payette et al., 2004; Zalatan et al., 2006), we suggest that the oral histories of Dënesọ́łıné peoples provide useful data about historic movement patterns of the Bathurst caribou from the 1920s-2000s; when these narratives are coupled with dendroecology data, an even greater understanding of caribou movement patterns are possible. These insights contribute to the body of knowledge about barrenground caribou ecology in the region and are consistent with the interpretations of previous research (Zalatan et al., 2006). The outcome of this study, which combined dendroecological data with oral history, is particularly valuable given the absence of other movement data (i.e., satellite collar data) for the Pedacho Kué area prior to the mid-1990s. Our approach is also aligned with other examples of ecological research that seek a complementary use of Indigenous and science-based methods of data collection and analysis (Service et al., 2014).

Although making cause-effect determinations is difficult, our work affirms the narratives of Dënesớłıné and other Indigenous Elders who have long argued that mining was "driving the caribou away" in recent decades (Parlee and Caine, 2018). The knowledge offered here provides key observations of shifts in caribou use and distribution of other species such as muskox. Elders and hunters validate long-standing community concerns about the impacts of climate change in their region and demonstrate a depth of knowledge about caribou movement in the Pedacho Kué region, including the sociocultural context of those changes, as with Eddie Drybones telling of the caribou decline in the 1930s that was met with government-led wolf poisoning in an effort to limit predation on declining caribou.

By addressing gaps in historical data based on both Indigenous knowledge and scientific methods, we can lend support and inspiration to those seeking to bring forward the strengths of both ways of knowing. This paper provides an example of collaborative, place-based approaches to ecological research, aligned with existing studies that have brought together knowledge from both Indigenous and science-based perspectives in wildlife monitoring and management (Danielsen et al., 2014; Service et al., 2014; Alexander et al., 2019; Cuyler et al., 2020). Our communitydirected approach that privileges local expertise, builds local research capacity, and seeks out methods to support the collection of relevant quantitative data is offered as an example of ethical, collaborative place-based research, producing a more holistic view of this complex socioecological system.

The dendroecology sampling and analysis provide a relatively limited set of quantitative results; however, when interpreted alongside previous data (Zalatan et al., 2006) and Indigenous, place-based narratives, the analysis provides data on the historic record of caribou use in the Pedacho Kue area and the Bathurst caribou range more broadly. Future collaborative research with ŁKDFN could explore additional fine-scale assessment of caribou use at Pedacho Kué between 1995-2006 to clarify some of the discrepancies found between our trample scar data, Elder and hunter observations, and previous trample scar assessment (Zalatan et al., 2006). Given that the dendroecology method has been demonstrated to be 
useful in mapping historic use by other mammal species, including moose (Morneau and Payette, 1998), there are many opportunities to build upon the framework offered here to meaningfully engage Indigenous communities and knowledges in such ecological research, producing knowledge that draws from the strengths of each approach. Learning from Madeline Drybones' interpretation that the trees do indeed have stories to tell, we can understand more deeply that it is the land that we learn from and that science and research practice more broadly simply provide the tools for us to document, interpret, and share those stories within the academy and, in some cases, within policy environments. By engaging in meaningful and ethical ways with Indigenous peoples and place-based knowledges, we can more fully interpret the stories offered by the land, as we work to ensure the long-term health of caribou, the land, and Dënesớłıné lifeways.

\section{ACKNOWLEDGEMENTS}

This paper is dedicated to the Elders and members of Łutsël K'e Dëne First Nation, with special honoring of those who have passed on since the completion of this project. Funding was provided by the Social Sciences and Humanities Research Council of Canada CGS-M Scholarship and W. Garfield Weston Award for Northern Research (Masters) awarded to K. Dokis-Jansen. Fieldwork was supported by a grant from the Northern Scientific Training Program awarded to K. Dokis-Jansen, and project funds from Diavik Diamond Mines Inc. supported the community field research camp and hiring of community researchers and translators. Funding for community researcher attendance at conference presentations was provided by Resources and Sustainable Development in the Arctic. Additional project and travel support were provided by Wildlife Conservation Society of Canada and Alberta Network Environments for Aboriginal Health Research grants awarded to K. Dokis-Jansen. Administrative and logistical support for the project was provided by the ŁKDFN Office, the Wildlife, Lands and Environment Office, and the Ni Hat'ni Dëne Guardians Program, namely Gloria Enzoe, the Ni Hat'ni Dëne Guardians Coordinator, who provided considerable guidance on field camp logistics and community engagement protocol for the project. Dennis Drygeese, Terrie Enzoe, and Florence Catholique, Dënesgliné language speakers with extensive research experience, supported the translation, transcription, and verification of interviews and terminology for this manuscript. We would also like to thank the reviewers of this manuscript for their insightful and generative feedback.

\section{REFERENCES}

Adamczewski, J., Boulanger, J., Sayine-Crawford, H., Nishi, J., Cluff, D., Williams, J., and LeClerc, L.-M. 2019. Estimates of breeding females \& adult herd size and analyses of demographics for the Bathurst herd of barren-ground caribou: 2018 calving ground photographic survey. Manuscript Report No. 279. Yellowknife: Environment and Natural Resources, Government of Northwest Territories. 138 p. https://www.enr.gov.nt.ca/sites/enr/files/resources/279 manuscript.pdf\#: :text=The $\% 20$ resulting $\% 20$ estimate $\% 20$ of $\% 20$ Bathurst,in $\% 20$ overall $\% 20$ herd $\% 20$ size $\% 2058.5 \% 25$

Agrawal, A. 1995. Dismantling the divide between Indigenous and scientific knowledge. Development and Change 26(3):413-439. https://doi.org/10.1111/j.1467-7660.1995.tb00560.x

Alexander, S.M., Provencher, J.F., Henri, D.A., Taylor, J.J., and Cooke, S.J. 2019. Bridging Indigenous and science-based knowledge in coastal and marine research, monitoring, and management in Canada: A systematic map protocol. Environmental Evidence 8(1): 15. https://doi.org/10.1186/s13750-019-0159-1

Anadón, J.D., Giménez, A., Ballestar, R., and Pérez, I. 2009. Evaluation of local ecological knowledge as a method for collecting extensive data on animal abundance. Conservation Biology 23(3):617-625. https://doi.org/10.1111/j.1523-1739.2008.01145.x

Baskin, L.M. 2003. River crossings as principal points of human/ reindeer relationship in Eurasia. Rangifer 23(5):37-40. https://doi.org/10.7557/2.23.5.1653

Berkes, F. 1983. Quantifying the harvest of native subsistence fisheries. In: Wein, R.R., Riewe, R.R., and Methven, I.R., eds. Resources and dynamics of the boreal zone. Proceedings of a Conference held at Thunder Bay, Ontario, August 1982. Ottawa: Association of Canadian Universities for Northern Studies. 346-363.

Berkes, F., Colding, J., and Folke, C. 2000. Rediscovery of traditional ecological knowledge as adaptive management. Ecological Applications 10(5):1251-1262.

https://doi.org/10.1890/1051-0761(2000)010[1251:roteka]2.0. co;2

Boudreau, S., Payette, S., Morneau, C., and Couturier, S. 2003. Recent decline of the George River caribou herd as revealed by tree-ring analysis. Arctic, Antarctic, and Alpine Research 35(2):187-195.

https://doi.org/10.1657/1523-0430(2003)035[0187:rdotgr]2.0. co;2

Boulanger, J., and Gunn, A. 2007. Exploring possible mechanisms for the decline of the Bathurst herd of barren-ground caribou using demographic modeling. Manuscript Report No. 175. Yellowknife; Environment and Natural Resources, Government of the Northwest Territories. https://www.arlis.org/docs/vol1/I/187131468.pdf

Boulanger, J., Gunn, A., Adamczewski, J., and Croft, B. 2011. A data-driven demographic model to explore the decline of the Bathurst caribou herd. The Journal of Wildlife Management 75(4):883-896.

https://doi.org/10.1002/jwmg.108 
CBC News. 2011. De Beers' mine plans raise caribou concerns. https://www.cbc.ca/news/canada/north/de-beers-mine-plansraise-caribou-concerns-1.1027251

COSEWIC (Committee on the Status of Endangered Wildlife in Canada). 2016. Caribou (Rangifer tarandus) barren-ground population COSEWIC assessment and status report 2016. Ottawa: COSEWIC. xiii +123 p.

https://www.canada.ca/en/environment-climate-change/ services/species-risk-public-registry/cosewic-assessmentsstatus-reports/caribou-barren-ground-population-2016.html

Cuyler, C., Daniel, C.J., Enghoff, M., Levermann, N., MøllerLund, N., Hansen, P.N., Damhus, D., and Danielsen, F. 2020. Using local ecological knowledge as evidence to guide management: A community-led harvest calculator for muskoxen in Greenland. Conservation Science and Practice 2(3): e159.

https://doi.org/10.1111/csp2.159

Cybis Electronik \& Data AB. 2013a. CooRecorder version 7.5. Saltsjöbaden, Sweden. https:/www.cybis.se/forfun/dendro/helpcoorecorder7/

___ 2013b. CDendro version 7.5. Saltsjöbaden, Sweden. https://www.cybis.se/forfun/dendro/

Danielsen, F., Topp-Jørgensen, E., Levermann, N., Løvstrøm, P., Schiøtz, M., Enghoff, M., and Jakobsen, P. 2014. Counting what counts: Using local knowledge to improve Arctic resource management. Polar Geography 37(1):69-91.

https://doi.org/10.1080/1088937x.2014.890960

Davis, A., and Wagner, J.R. 2003. Who knows? On the importance of identifying "experts" when researching local ecological knowledge. Human Ecology 31(3):463 - 489. https://doi.org/10.1023/A:1025075923297

Duerden, F., and Kuhn, R.G. 1998. Scale, context, and application of traditional knowledge of the Canadian North. Polar Record 34(188):31-38.

https://doi.org/10.1017/s0032247400014959

Ellis, S.C. 2005. Meaningful consideration? A review of traditional knowledge in environmental decision making. Arctic 58(1):66-77.

https://doi.org/10.14430/arctic390

Festa-Bianchet, M., Ray, J.C., Boutin, S., Côté, S.D., and Gunn, A. 2011. Conservation of caribou (Rangifer tarandus) in Canada: An uncertain future. Canadian Journal of Zoology 89(5):419-434.

https://doi.org/10.1139/z11-025

Gagnon, C., and Berteaux, D. 2009. Integrating traditional ecological knowledge and ecological science: A question of scale. Ecology and Society 14(2): 19.

https://doi.org/10.5751/es-02923-140219

Giles, A.R., and Castleden, H. 2008. Community co-authorship in academic publishing: A commentary. Canadian Journal of Native Education 31(1):208-213, 318-319.

GNWT (Government of Northwest Territories). 2019. Bathurst caribou range plan. Yellowknife: Environment and Natural Resources, Government of Northwest Territories. $86+$ iii p. https://www.enr.gov.nt.ca/sites/enr/files/resources/ bathurst_caribou_range_plan_2019_-_plan_pour_laire_de repartition_des_caribous_de_bathurst_2019.pdf
Gordon, B.C. 2005. 8000 years of caribou and human seasonal migration in the Canadian Barrenlands. Rangifer 25(4):155-162.

https://doi.org/10.7557/2.25.4.1780

Gunn, A., Poole, K., and Wierzchowski, J. 2011. Migratory tundra caribou seasonal and annual distribution relative to ThaiDëne Nene, a national park reserve proposal in the East Arm of Great Slave Lake and Artillery Lake area, Northwest Territories. Fort Smith: Parks Canada.

Huntington, H.P. 1998. Observations on the utility of the semidirective interview for documenting traditional ecological knowledge. Arctic 51(3):237-242. https://doi.org/10.14430/arctic1065

IPBES (Intergovernmental Science-Policy Platform on Biodiversity and Ecosystem Services). 2019. Summary for policymakers of the global assessment report on biodiversity and ecosystem services of the Intergovernmental SciencePolicy Platform on Biodiversity and Ecosystem Services. Bonn, Germany: IPBES secretariat. 56 p. https://ipbes.net/sites/default/files/2020-02/ipbes_global_ assessment_report_summary_for_policymakers_en.pdf

Jacobsen, P., Chocolate, G., Wetrade, R., and Birlea, M. 2016. Ekwò zò gha dzô nats'êdè "We live here for caribou:" Cumulative impacts study on the Bathurst caribou. Dedats’eetsaa: Tłıcho Research and Training Institute, Yellowknife.

https://research.tlicho.ca/sites/default/files/ekwo_zo_gha dzo_natsede_tk_study.pdf

Kendrick, A., and Manseau, M. 2008. Representing traditional knowledge: Resource management and Inuit knowledge of barren-ground caribou. Society \& Natural Resources 21(5):404-418. https://doi.org/10.1080/08941920801898341

Kendrick, A., Lyver, P.O’B., and Łutsël K’e Dëne First Nation. 2005. Dënesôliné (Chipewyan) knowledge of barren-ground caribou (Rangifer tarandus groenlandicus) movements. Arctic 58(2):175-191. https://doi.org/10.14430/arctic409

Kutz, S., Veitch, A., Branigan, M., Lambert, C., Wright, W., Elkin, B., Bayha, J., and Guthrie, G. 2005. Using hunter observations and ecological knowledge together with science to understand past and current occurrence of wildlife diseases in the North. Hunter Observations of Wildlife Diseases, Report to INAC. https:/nwtdiscoveryportal.enr.gov.nt.ca/geoportaldocuments/ cimp_2005-Using\%20Hunter $\% 20$ Observations $\% 20$ and $\% 20$ Ecological\%20Knowledge\%20Together\%20With\%20Science. pdf

Legat, A., Chocolate, G., Gon, B., Zoe, S.A., and Chocolate, M. 2001. Caribou migration and the state of their habitat. Final Report from Dogrib Treaty 11 Council. Yellowknife: West Kitikmeot Slave Study Society.

https://www.enr.gov.nt.ca/sites/enr/files/wkss_caribou_ migration_and_habitat_2001.pdf 
Łutsël K'e Dëne First Nation. 2016. Written response to the EA1314-01 report of environmental assessment and reasons for decision for the Jay Project, Dominion Diamond Ekati Corporation. Yellowknife: Mackenzie Valley Environmental Impact Review Board.

http://www.reviewboard.ca/upload/project_document/ EA1314-01_LKDFN_letter_to_NPMO_4Apri12016_re_Jay_ project.PDF

Lyver, P.O’B, and Łutsël K’e Dëne First Nation. 2005. Monitoring barren-ground caribou body condition with Dënesọłıné traditional knowledge. Arctic 58(1):44-54.

https://doi.org/10.14430/arctic388

Morneau, C., and Payette, S. 1998. A dendroecological method to evaluate past caribou (Rangifer tarandus L.) activity. Écoscience 5(1):64-76. https://doi.org/10.1080/11956860.1998.11682446

___ 2000. Long-term fluctuations of a caribou population revealed by tree-ring data. Canadian Journal of Zoology 78:1784-1790.

https://oi.org/10.1139/z00-122

MVEIRB (Mackenzie Valley Environmental and Impact Review Board). 2016. EA14314-01: Jay Project, Dominion Diamond Łutsël K'e community hearing. Łutsël K'e: MVEIRB. 272 p.

Nadasdy, P. 2003. Reevaluating the co-management success story. Arctic 56(4):367-380. https://doi.org/10.14430/arctic634

Nagy, J.A., Wright, W.H., Slack, T.M., and Veitch, A.M. 2005. Seasonal ranges of the Cape Bathurst, Bluenose-West, and Bluenose-East barren-ground caribou herds. Manuscript Report No. 167. Yellowknife: Environment and Natural Resources, Government of the Northwest Territories.

https://www.srrb.nt.ca/index.php?option $=$ com docman $\&$ view $=$ download $\&$ alias $=1410$-seasonal-ranges of-the-cape-bathurst-bluenose-west-and-bluenose-eastbarren-ground-caribou-herds\&category_slug=responses-toinformation-requests \&Itemid $=697$

Nishi, J., Legat, A., Adamczewski, J., Pellissey, J., Cluff, H.D., Clark, K., and Sayine-Crawford, H. 2018. Undermining comanagement of Bathurst caribou in the Northwest Territories. Comments on "Undermining subsistence: Barren-ground caribou in a "tragedy of open access," by B.L. Parlee, J. Sandlos and D.C. Natcher. Science Advances 4(2): e1701611. https://doi.org/10.1126/sciadv.1701611

Noble, W.C. 1971. Archaeological surveys and sequences in central District of Mackenzie, N.W.T. Arctic Anthropology 8(1):102- 135 .

Parlee, B.L., and Caine, K.J., eds. 2018. When the caribou do not come: Indigenous knowledge and adaptive management in the Western Arctic. Vancouver, British Columbia: UBC Press.

Parlee, B., Manseau, M., and Łutsël K'e Dëne First Nation. 2005a. Using traditional knowledge to adapt to ecological change: Dënesớłıné monitoring of caribou movements. Arctic 58(1):26-37.

https://doi.org/10.14430/arctic386 2005b. Understanding and communicating about ecological change: Dënesọłıné indicators of ecosystem health. In: Berkes, F., Huebert, R., Fast, H. and Diduck, A., eds. Breaking ice: Integrated ocean management in the Canadian North. Calgary, Alberta: University of Calgary Press. 165-182. https://doi.org/10.2307/j.ctv6gqvp5.15

Parlee, B.L., Sandlos, J., and Natcher, D.C. 2018. Undermining subsistence: Barren-ground caribou in a "tragedy of open access.” Science Advances 4(2): e1701611.

https://doi.org/10.1126/sciadv.1701611

Payette, S., Boudreau, S., Morneau, C., and Pitre, N. 2004. Long-term interactions between migratory caribou, wildfires and Nunavik hunters inferred from tree rings. Ambio 33(8):482-486.

https://doi.org/10.1579/0044-7447-33.8.482

Pedersen, S., and Coffing, M. 1984. Caribou hunting: Land use dimensions and recent harvest patterns in Kaktovik, northeast Alaska. Technical Paper No. 92. Fairbanks: Alaska Department of Fish and Game, Division of Subsistence.

Peloquin, C., and Berkes, F. 2009. Local knowledge, subsistence harvests, and social-ecological complexity in James Bay. Human Ecology 37(5):533-545. https://doi.org/10.1007/s10745-009-9255-0

Polfus, J.L., Manseau, M., Simmons, D., Neyelle, M., Bayha, W., Andrew, F., Andrew, L., Klütsch, C.F.C., Rice, K., and Wilson, P. 2016. Łeghágots'enetę (learning together): The importance of Indigenous perspectives in the identification of biological variation. Ecology and Society 21(2): 18.

https://doi.org/10.5751/ES-08284-210218

Rist, J., Milner-Gulland, E.J., Cowlishaw, G.U.Y., and Rowcliffe, M. 2010. Hunter reporting of catch per unit effort as a monitoring tool in a bushmeat-harvesting system. Conservation Biology 24(2):489-499.

https://doi.org/10.1111/j.1523-1739.2010.01470.x

Schnarch, B. 2004. Ownership, control, access, and possession (OCAP) or self-determination applied to research: A critical analysis of contemporary First Nations research and some options for First Nations communities. International Journal of Indigenous Health 1(1):80-95.

Service, C.N., Adams, M.S., Artelle, K.A., Paquet, P., Grant, L.V., and Darimont, C.T. 2014. Indigenous knowledge and science unite to reveal spatial and temporal dimensions of distributional shift in wildlife of conservation concern. PLoS ONE 9(7): e101595. https://doi.org/10.1371/journal.pone.0101595

Smith, J.G.E. 1978. Economic uncertainty in an "original affluent society": Caribou and caribou eater Chipewyan adaptive strategies. Arctic Anthropology 15(1):68-88.

Stewart, A.M., Keith, D., and Scottie, J. 2004. Caribou crossings and cultural meanings: Placing traditional knowledge and archaeology in context in an Inuit landscape. Journal of Archaeological Method and Theory 11(2):183-211. https://doi.org/10.1023/b:jarm.0000038066.09898.cd

Stokes, M.A., and Smiley, T.L. 1968. An introduction to tree-ring dating. Chicago, Illinois: University of Chicago Press. 
Taylor, J.J., Lawler, J.P., Aronsson, M., Barry, T., Bjorkman, A.D., Christensen, T., Coulson, S.J., et al. 2020. Arctic terrestrial biodiversity status and trends: A synopsis of science supporting the CBMP State of Arctic Terrestrial Biodiversity Report. Ambio 49(3):833-847. https://doi.org/10.1007/s13280-019-01303-w

Thorpe, N., Hakongak, N., Eyegetok, S., and Qitirmiut Elders. 2001. Tuktu and Nogak Project: A caribou chronicle. Final report to the West Kitikmeot / Slave Study Society. Ikaluktuuttiak, Nunavut.

http://www.enr.gov.nt.ca/sites/enr/files/wkss_tuktu_ nogak_2001.pdf

Usher, P.J., and Wenzel, G. 1987. Native harvest surveys and statistics: A critique of their construction and use. Arctic 40(2): $145-160$. https://doi.org/10.14430/arctic1759

Vors, L.S., and Boyce, M.S. 2009. Global declines of caribou and reindeer. Global Change Biology 15(11):2626-2633. https://doi.org/10.1111/j.1365-2486.2009.01974.x
Wek'èezhìı Renewable Resources Board. 2019. Reasons for decisions related to a joint proposal for the management of the Kǫk'èetì Ekwọ̀ (Bathurst caribou) herd.

https://www.nw mb.com/iku/conservation-education/ list-all-documents/public-hearings/2020/in-personpublic-hearing-to-consider-the-government-of-nunavuts-proposal-to-decrease-the-total-allowable-harvestfor-bathurst-caribou-from-30-to-0/submissions-34/ wek-eezhii-renewable-resources-board-submission/8159-kokeeti-ekwo-report-final/file

Williams, T.M., and Gunn, A. 1982. Descriptions of water crossings and their use by migratory barren-ground caribou in the districts of Keewatin and Mackenzie, N.W.T. File Report No. 27. Yellowknife: NWT Wildlife Service. https://www.enr.gov.nt.ca/sites/enr/files/27.pdf

Zalatan, R., Gunn, A., and Henry, G.H.R. 2006. Long-term abundance patterns of barren-ground caribou using trampling scars on roots of Picea mariana in the Northwest Territories, Canada. Arctic, Antarctic, and Alpine Research 38(4):624-630. https://doi.org/10.1657/1523-0430(2006)38[624:lapobc]2.0.co;2 